\title{
POLITIKA ARCHITEKTURY A STAVEBNÍ KULTURY ČESKÉ REPUBLIKY A JEJÍ AKTUALIZACE
}

\author{
ARCHITECTURE AND BUILDING CULTURE POLICY OF THE CZECH \\ REPUBLIC AND ITS UPDATES
}

Jakub Kotrla ${ }^{1,2}$

Adam Guzdek ${ }^{2}$

*jakub.kotrla@vutbr.cz

${ }^{1}$ Ústav architektury, Fakulta stavební, VUT v Brně, Veveří 331/95, 60200 Brno

${ }^{2}$ Ústav pozemního stavitelství, Fakulta stavební, VUT v Brně, Veveři 331/95, 60200 Brno

\begin{abstract}
Abstrakt
Článek se zabývá dokumentem o architektuře a stavební kultuře, popisuje a prozkoumává stávající celorepublikový dokument/strategii Politiku architektury a stavební kultury České republiky. Zároveň popisuje podklady, které v roce 2020 vznikaly jako východisko pro aktualizaci tohoto dokumentu ve spolupráci i České komory architektů, České komory autorizovaných techniků činných ve výstavbě a Asociace pro urbanismus a územní plánování. Navíc se seznamuje i s evropským kontextem hodnocení architektury pro každého jakožto součástí vystavěného prostředí. Cílem je tak představit tento dokument, cestu jeho vývoje i plány v probíhající aktualizaci.
\end{abstract}

\section{Klíčová slova}

Politika architektury a stavební kultury, PASK ČR, architektura, architektura pro všechny, kritéria kvality, Česká republika

\begin{abstract}
The article deals with a document on architecture and building culture, describes and explores the existing nationwide document/strategy Architecture and Building Culture Policy of the Czech Republic. At the same time, it describes the documents that were created in 2020 as a starting point for updating this document in cooperation with the Czech Chamber of Architects, the Czech Chamber of Authorized Technicians Active in Construction and the Association for Urban Planning and Regional Planning of the Czech Republic. In addition, it acquaints with the European context of architecture evaluation for everyone as part of the built environment. The aim is to present this document, the path of its development and plans in the current update.
\end{abstract}

\section{Key words}

Architecture and building culture policy, PASK ČR, architecture, architecture for everyone, quality criteria, Czech republic

\section{1 ÚVOD}

Článek řeší vývoj pohledu na architekturu a stavební kulturu pomocí strategického dokumentu na úrovni státu Politiky architektury a stavební kultury České republiky (dále jen PASK ČR). Jedná se o celostátní strategii, která nastiňuje cíle a vize ve střednědobém až dlouhodobém horizontu. Článek se zabývá přehledem historického vývoje dokumentu a posléze rozebírá př́ípravu aktualizace dokumentu, která probíhá cca od března roku 2021. Pořizovatelem materiálu je Ministerstvo pro místní rozvoj, zpracovatelem strategie je Ústav územního rozvoje. Autor článku se na prrípravě dokumentu podílí v roli garanta úkolu a zpracovatele.

Se schválením nového stavebního zákona, tedy zákona č. 283/2021 Sb., byla PASK ČR zakotvena tímto zákonem jako nástroj územního plánování, stejně jako územně plánovací podklady (územně analytické podklady a územní studie), územně plánovací dokumentace (územní rozvojový plán, zásady územního rozvoje, územní plán a regulační plán), vymezení zastavěného území a územní opatření (územní opatření o stavební uzávěře a územní opatření o asanaci území). Byly také upraveny cíle a úkoly územního plánování v souvislosti s PASK ČR, konkrétně $\$ 38$ odstavec 3, který zní „Cílem územního pánování je také zvyšovat kvalitu vystavěného prostredi 
sídel, rozvijet jejich identitu a vytvářet funkční a harmonické prostředi pro každodenní život jejich obyvatel“ [1]. Tím by se měl dokument dostávat do povědomí nejenom pro orgány státní správy a samosprávy, organizačním složkám státu a ústř̌edním orgánům státní správy, ale také profesním komorám a odborným skupinám, včetně veřejnosti. Plněním vytyčených cílů a opatření se tak řeší podpora rozvoje architektury a stavební kultury jako principu zvyšování kvality prostředí vytvářeného výstavbou pro zlepšení kvality života obyvatel.

Kvalitou prostředí vytvářeného výstavbou pro zlepšení kvality života obyvatel se zabývá také OMC Group (Open Method of Coordination), která na základě pověření Evropské komise od vydání Davoské deklarace pracovala na kritériích pro vysoce kvalitní architekturu. Deklarace vyzývala $\mathrm{k}$ holistickému př́stupu, který zdůrazňuje odpovědnost společnosti pro vystavěné prostředí. Výsledkem Baukultur (česky podobné stavební kultuře, vystavěnému prostředí) je vysoce kvalitní prostor. V ř́ijnu 2021 tak OMC Group zveřejnila na mezinárodní konferenci k politikám architektury konající se při př́ležitosti předsednictví Slovinska v Radě EU závěrečnou zprávu, která obsahuje materiál „Davos Baukultur Quality System“, která hodnotí vysoce kvalitní vystavěné prostředí pomocí osmi kritérií - vláda (vysoká kvalita Baukultur následuje dobré vládnutí), funkčnost (vysoce kvalitní Baukultur vyhovuje účelu), prostředí (vysoce kvalitní Baukultur chrání prostředí), ekonomika (vysoce kvalitní Baukultur dodává ekonomickou hodnotu), rozmanitost (vysoce kvalitní Baukultur spojuje lidi), kontext (vysoce kvalitní Baukultur má výsledky v prostorové koherenci), smysl pro místo (vysoce kvalitní Baukultur zlepšuje smysl pro místo) a krása (vysoce kvalitní Baukultur je krásné) [2]. I tyto principy vyplývají z Davoské deklarace a zpřesňující tímto materiálem ovlivňují proces aktualizace PASK ČR.

\section{LITERÁRNÍ PŘEHLED/POPIS SOUČASNÉHO STAVU}

Dokument se vyvíjel cca od roku 2010, kdy Ministerstvo pro místní rozvoj zadalo Ústavu územního rozvoje a jeho externím spolupracovníkům a odborným komorám zpracování dokumentu jakožto přípravy návrhu „Politiky architektury České republiky - národního programu stavebni kultury“. Tento dokument provedl analýzu politik architektury vybraných evropských zemí, dále shrnul požadavky vyplývající z dokumentů EU, vztahující se $\mathrm{k}$ problematice kvality prostředí tvořeného výstavbou (dnes vystavěného prostředí), a nastínil problémy, jimiž je třeba se zabývat ke zvýšení kultury výstavby. Závěrem doporučil principy formy a koncepce pro národní dokument české republiky [3]. Byl dokončen v březnu roku 2011.

Dalším krokem bylo vydání materiálu ,Analýza stavební kultury - Podklad pro řešení problematiky - Politika rozvoje stavební kultury (Architektury) “. Tento dokument z roku 2012 navazuje na usnesení vlády č. 524 ze dne 13. 7. 2011, kterým byla schválena Koncepce bydlení České republiky do roku 2020 a kterým se formálně zadalo pořizení dokumentu „Politiky rozvoje stavební kultury“. Analýza byla členěna do sedmi tematických okruhů: Estetická kvalita staveb; Energetická náročnost staveb; Životnost a udržitelnost staveb, trvalost stavebního díla. Pořizovací a provozní náklady; Začlenění staveb do území - stavby v kontextu svého prostředí; Veřejná prostranství; Prostorové uspořádání sídel, dostupnost/napojení; Podpora stavební kultury ve školství, výzkumu a vývoji. Tyto tematické okruhy se vzájemně překrývaly a také se ukazovalo, že v některých případech jsou ve vzájemném př́íčinném nebo hierarchickém vztahu. Komplementem analýzy pak bylo sociologické šetření mezi vybranými odborníky - architekty, urbanisty, teoretiky a pracovníky veřejné správy. Výsledky dokumentu také ukázaly, že o řadě témat související právě s tématem stavební kultury a prostředím sídel existuje ve veřejném prostoru diskuze, i vyhraněné názory na problémy i př́ipadná řešení [4].

Diskuze se také stočila k jednotlivým terminologiím, které dokument provázely, a to pojmy stavební kultura a prostředí vytvářené výstavbou. Stavební kultura je součástí kultury obecné, tedy toho, jaké hodnoty jednotlivci i celá společnost zastávají, sdílejí, respektují, rozvíjejí, chrání a prosazují. Předmětem stavební kultury je především fyzické - hmotné prostředí staveb a sídla, ale ve vztahové rovině má stavební kultura řadu sociálních atributů. Pojem stavební kultury tedy popisuje proces vývoje zastavěného prostředí a náš prístup $\mathrm{k}$ němu. Zahrnuje plánování, výstavbu, rekonstrukci a údržbu. Stavební kultura v sobě zahrnuje nejen pohled a odbornost architektury, ale i stavebního inženýrství, územní a regionální plánování, krajinnou architekturu i veřejné umění. Kvalita stavební kultury je přímo úměrná odpovědnosti, kterou pocit’uje celá společnost za zastavěné prostředí a za jeho údržbu. Druhý jmenovaný pojem, tedy prostředí vytvářené výstavbou, se v současnosti již nepoužívá, ale nahrazuje se ,vystavěným prostředím“. Z hlediska obsahu však znamená stále stejný obsah. Skládá se ze širokého rozsahu prvků od jednotlivých budov, prostranství, parků nebo ploch zeleně přes obytné čtvrti až po celá města. Zahrnuje též podpůrné infrastruktury, jako jsou systémy zabezpečující dopravní dostupnost, zásobování vodou nebo energetické sítě. Zahrnuje místa a prostory upravené nebo vytvořené lidmi včetně budov, parků a dopravních systémů [4], [5].

V současné době se jeden z řešených úkolů zabývá také výzkumy, které se zaměřují na vliv kvality prostředí na člověka. Tedy jak vystavěné prostředí na člověka působí. Materiál z roku 2012 také vyhodnocoval dosavadní koncepce rezortů a dotačních titulů a určitým významem jimi byl ovlivněn. Koncepce evropské unie představoval např́íklad dokument Evropa 2020, který obsahoval podněty pro rozvoj stavební kultury. Byly jimi například: 
- Architektura musí být vnímána jako projev kultury, který reprezentuje a dokumentuje dř́vější a současné způsoby života a společné hodnoty.

- Cílem musí být dosáhnout uspokojivého vzájemného působení mezi starým a novým a správné ochrany hodnot v krajině.

- Je třeba vědomě využívat nástroje pro dobrý společenský rozvoj a územní plánování, které usnadňují udržitelný rozvoj architektury.

- Stavební kultura a dobrá architektura se musí zaměřit na životní prostředí, univerzální design, dobrou kvalitu.

- Posouzení vlivu na životní prostředí je důležité také při volbě mezi zachováním stavby, novým využitím nebo novou stavbou.

Byly také reflektovány koncepce v České republice, mezi které patřila „Politika územního rozvoje České republiky z roku 2008“. Ta také jednoznačně definovala podněty pro Politiku rozvoje stavební kultury (architektury), kdy stanovila např́klad priority:

- Chránit a rozvíjet přírodní, civilizační a kulturní hodnoty území, včetně urbanistického, architektonického a archeologického dědictví.

- Zachovat ráz jedinečné urbanistické struktury území, struktury osídlení a jedinečné kulturní krajiny, které jsou výrazem identity území, jeho historie a tradice.

- Minimalizovat negativní důsledky suburbanizace pro udržitelný rozvoj území.

Tyto principy ve velké míře zůstávají platné i v aktuální Politice územního rozvoje České republiky (ve znění závazném od 1.9. 2021). Od roku 2008 byly tyto republikové priority při Aktualizaci č. 1, ale také při Aktualizaci č. 4 vždy prověřeny s ohledem na jejich rozsah, konkrétnost, jednoznačnost formulací a aktuálnost. Ty, které byly př́liš obecné, nebo nebylo možné naplnit navazujícími nástroji územního plánování, byly vypuštěny [6] [7].

Závěrem dokumentu byly zpracovány doporučení ke zpracování politiky rozvoje stavební kultury. V roce 2014 tak vznikl první pracovní návrh dokumentu, který již nesl název „Politika architektury a stavební kultury České republiky“. Ten byl zpracován podle „Metodiky př́pravy veřejných strategil“ schválené vládou 2. 5. 2013. Dokument pracoval s několika kapitolami a stanovoval vize, témata a strategické cíle. Dílčím dokumentem/př́lohou byl pak implementační plán, který konkretizoval cíle v jednotlivých opatřeních. Tyto opatření by měla vést k jejich naplnění a určovala vždy jednoho garanta, který je zodpovědný za naplnění opatření, spolupracující instituce, které se podílejí na naplňování opatření a termín, kdy by mělo být opatření naplněno.

Oficiálně byl dokument PASK ČR schválen usnesením vlády ze dne 14. ledna 2015 č. 22 a je platný doposud [5]. Vláda dále uložila svým usnesením č. 287 z 15. března 2021 zpracovat do konce roku 2022 aktualizaci dokumentu, při čemž má být zohledněn materiál „Politika architektury a stavebni kultury České republiky Náměty $k$ aktualizaci“.

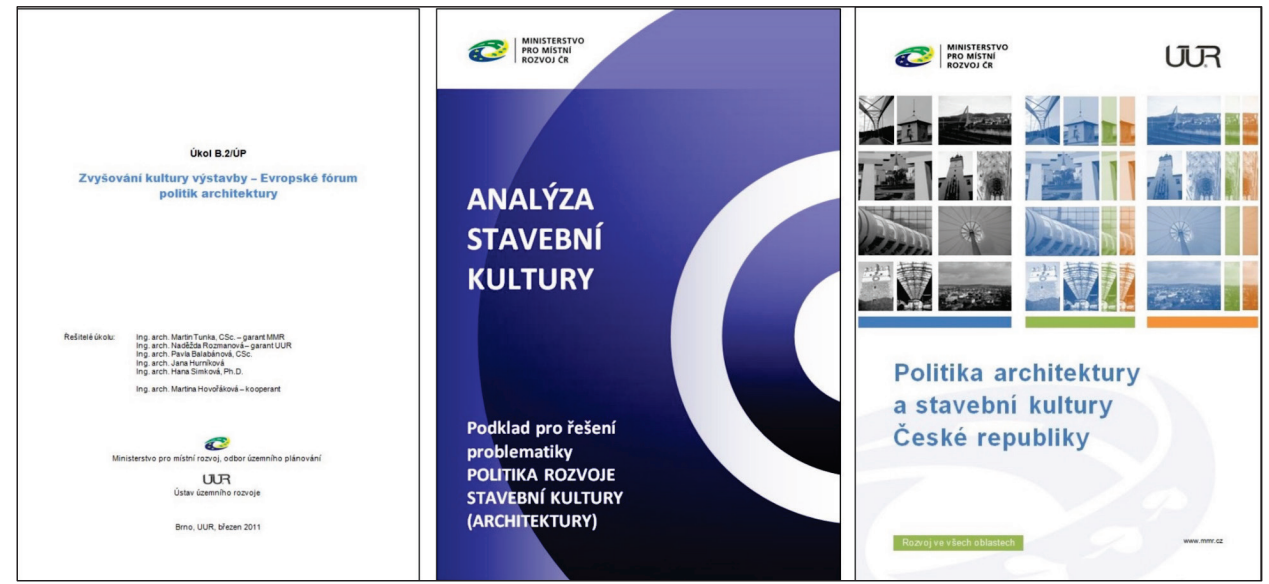

Obr. 1 Př́klady jednotlivých publikací před vydáním PASK ČR.

\section{METODIKA}

Struktura dokumentu vychází z ,Metodiky prípravy veřejných strategil““. Ta rámcově představuje jednotlivé kapitoly a obsahové náležitosti. Na základě toho byla PASK ČR zpracována. 
Aktualizace dokumentu se však snaží strukturu zjednodušit a materiál koncipovat jako strategii sloužící převážně pro orgány státní správy a samosprávy. Tedy stručný a jasný materiál bez zbytečného množství textu a grafických př́loh. Zaměřuje se primárně na určení cílů a následných opatření, které by měly být implementovány. Dokument musí také reflektovat stávající platné dokumenty a koncepce, jako např. Politiku územního rozvoje České republiky (ve znění závazném od 1.9. 2021), Strategii regionálního rozvoje 2021+, nebo také Davoskou deklaraci schválenou ministry kultury států evropské unie 22. 1. 2018.

Aktualizace dokumentu reflektuje materiál schválený 14. ledna 2015. Materiál je tedy zpracováván formou srovnávacího textu, tedy formou ,stávajici text černě - text k odstranění modře přeškrknutý - nový text červeněc“. Srovnávací text je materiál pro konzultace a který poukazuje na rozdíly, které aktualizace přináší. Lze tak na první pohled vidět, jaké změny byly provedeny, případně se jednoduše vrátit k původnímu návrhu. Zpracovatelský tým také použivá systém komentářů, kde lze psát poznámky, př́ípadně nejasnosti pro další projednávání. Každá změna platného materiálu tak má svůj zdroj/pokyn, proč došlo právě k této změně, nebo čím byla způsobena. Pro tento strategický materiál však nevzniká povinnost, tak jako pro jiné, aby byl následně ze srovnávacího textu vytvořen bodový text (tzv. právnický materiál, který reflektuje každou provedenou změnu ke stávající platné strategii) nebo materiál odůvodnění (materiál, který každou provedenou změnu odůvodňuje). Komentáře v textu však určitou formu odůvodnění umožňují, ale jen jako podklad pro jednání pracovní skupiny, aby bylo možné argumentovat zpracovatelem, na základě jakých skutečností byla potřeba provést konkrétní úpravu. Tyto zmíněné materiály však stále nebudou konečným materiálem pro schválení vládou. Po ukončení jednání pracovní skupiny a povinným legislativním procesem připomínkování ze strany ministerstev a orgánů státní správy, případně obcí a veřejnosti bude materiál upraven do tzv. čistopisu, tedy pouze černý schválený text. Vznikne tak jednotně vypadající materiál, který po dokončení bude předložen vládě ke schválení.

Materiál, jak již bylo řečeno, bude sloužit převážně pro orgány státní správy a samosprávy, kterým bude určovat pokyny, případně doporučení a zodpovědným institucím za jednotlivá opatření konkretizuje i termíny splnění. Jedním z navržených opatřeních je však také pro Ústav územního rozvoje, aby do konce roku 2023 zpracoval materiál srozumitelný široké veřejnosti, shrnující základní principy PASK ČR. Právě na zaměření materiálu při aktualizaci nebyla jednoznačná shoda, jak materiál uchopit a pro koho. Proto budou vytvořeny materiály dva, jeden oficiální, který bude aktualizací PASK ČR sloužící převážně pro státní správu a samosprávu a zainteresované subjekty, a posléze druhý materiál jako doprovodná část pro širokou veřejnost.

Tak jako v průběhu platnosti stávajícího materiálu bude i pro aktualizaci PASK ČR povinnost vyhodnocovat plnění jednotlivých opatření v čase a nejpozději na konci roku 2028 rozhodnout vládou na základě Zprávy o vyhodnocování Politiky architektury a stavební kultury České republiky o př́padné aktualizaci dokumentu nebo zpracování nového.

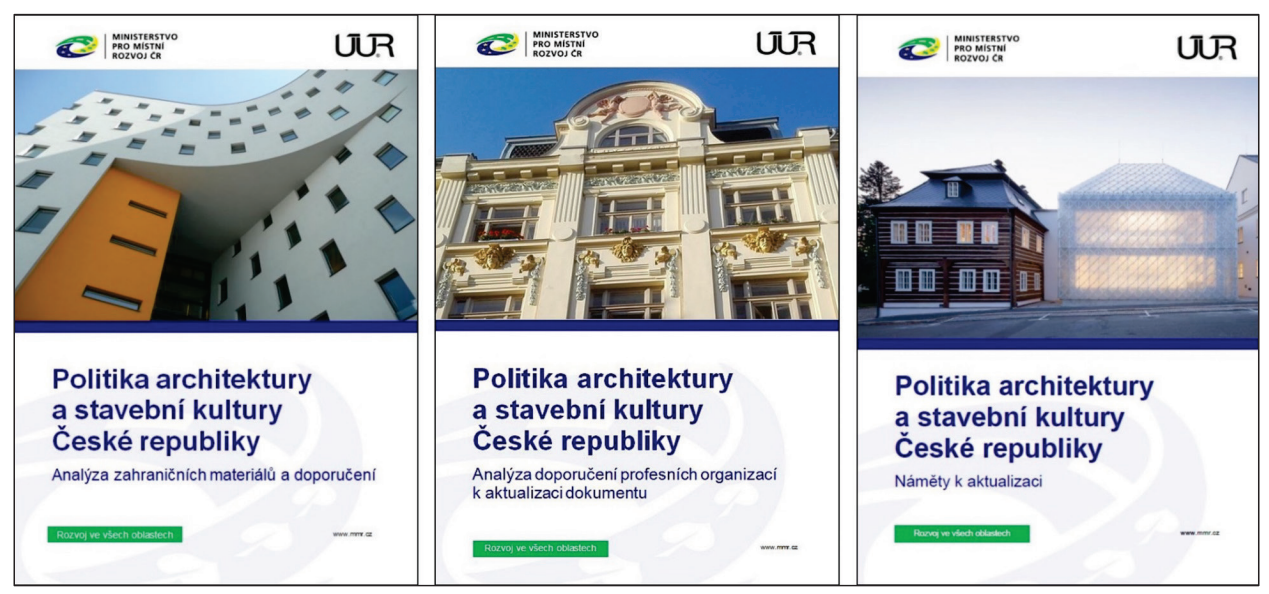

Obr. 2 Materiály analýzy k aktualizaci PASK ČR.

\section{VÝSLEDKY}

Pro správné vyhodnocení vhodnosti aktualizace dokumentu, byly zpracovány dvě vyhodnocení plnění PASK ČR, a to ke konci roku 2017 a 2020. Tyto dokumenty obsahovaly souhrn informací o plnění jednotlivých opatření, či jejich průběhu a také jednotlivých výsledcích. V rámci plnění opatření vznikly publikace nebo také jednotlivé 
metodiky, které mají užitek pro celý obor. Jedná se např. o publikaci „Požadavky na adaptaci sídel a uspořádání krajiny vyplývajicí ze strategických materiálü“ vycházející z opatření 1.1.6, metodiku „Možnosti pozitivního ovlivňování vývoje sídelní struktury nástroji územního plánováni" zadanou opatřením 1.1.3, motivační pomůcku „Principy a zásady urbanistické kompozice v př́kladech“ vycházející z opatření 1.2.3, metodický pokyn „Veřejná prostranství v územně analytických podkladech obcí a územních plánech" vycházející z opatření 2.1.2 a 2.1.4, publikaci „VEŘEJNÁ PROSTRANSTVÍ aneb jak udělat veřejný prostor dobř “"zadanou opatřením 2.2.3, publikaci „Charakter a struktura zástavby venkovských sídel v územnich plánech“ a připravované pokračování „Charakter a struktura zástavby městských sídel v územnich plánech“ danou opatřením 3.1.1, publikace „OBČANA ÚZEMNÍ PLÁNOVÁNÍ / Práva a povinnosti občanů v územním plánováni" a „OBEC A ÚZEMNÍ PLÁNOVÁNÍ / Postavení a činnost obcí v územním plánováni" vycházející z opatření 7.3.1 nebo také „Aktualizovaný seznam vybraných výsledků výzkumu I. Zdroj: Informační systém výzkumu, experimentálního vývoje a inovaci“ a „Aktualizovaný seznam vybraných výsledků výzkumů II. Zdroj: Knihovna ÚÚR - Novinky" dané opatřením 8.2.3 [8] [9].

Výsledkem procesu pořizování aktualizace PASK ČR je již v současnosti několik materiálůn, ze kterých samotná aktualizace PASK ČR vychází a nad jednotlivými navrženými úpravami se diskutuje. Prvním materiálem byl „Politika architektury a stavebni kultury České republiky - Analýza zahraničních materiálù a doporučeni“" Tento dokument shrnuje u každé jednotlivé zahraniční politice architektury její klady a zápory a př́ípadné možnosti, co by bylo možné aplikovat do českého dokumentu [10]. Dalším materiálem byl „Politika architektury a stavebni kultury České republiky - Analýza doporučení profesních organizací k aktualizaci dokumentu“. Byli zapojeni odborníci z České komory architektů, České komory autorizovaných techniků činných ve výstavbě a Asociace pro urbanismus a územní plánování. Opět byly tyto doporučení vyhodnoceny a uplatněny v návrhu aktualizace [11]. Následoval materiál „Politika architektury a stavební kultury České republiky - Náměty k aktualizaci“, který sjednotil doporučení z předešlých materiálů a vybral základní směr pro aktualizaci [12]. Byl již schválen vládou, ale neznamená to, že by musely všechny obsažené opatření být $\mathrm{v}$ aktualizaci přijímány. současnosti je k dispozici pracovní návrh srovnávacího textu aktualizace PASK ČR, který projednává pracovní skupina PASK. Posledním materiálem byl „Politika architektury a stavební kultury České republiky Výsledky souhrnné analýzy výstupi̊ $k$ aktualizaci dokumentu“. Tento materiál již sloučil všechny možná doporučení, specifikoval podle barevného označení tzv. semaforu, jejich možnosti uplatnění a sloužil jako „kuchařka“" nebo návod pro postup aktualizace PASK ČR [13].

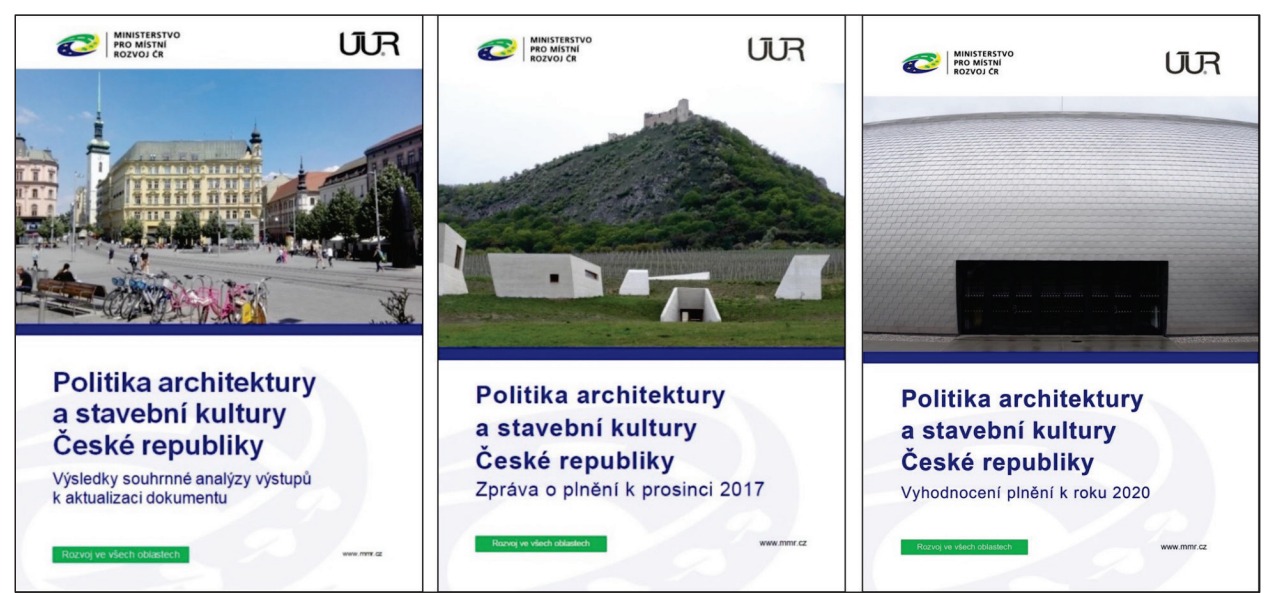

Obr. 3 Výsledky analýzy a plnění PASK ČR.

\section{DISKUZE}

Samotná strategie PASK ČR neznamená, že v České republice bude kvalitnější vystavěné prostředí a lepší kvalita života obyvatelstva. Dokument pokládá dlouhodobou vizi a směr, co je třeba zkoumat, zlepšovat, dělat a nad čím je třeba nalézt shoda. Spousta vydaných dokumentů zdánlivě s PASK ČR nesouvisí, ale př́i pozornějším studiu je nalezneme právě v jednotlivých opatřeních PASK ČR a tím se postupně PASK ČR implementuje. Nejdůležitějším je však ochota diskutovat, ochota lidí se zapojovat, ochota společnosti prostředí zlepšovat. Samotná strategie bez společenského konsenzu a zodpovědného prŕístupu nebude mít žádný efekt. 
Je třeba se obecně zaměřit na spolupráci s veřejností a podporovat jejich aktivní př́istup a zájem o to, co se děje a co je př́mo i nepř́mo ovlivňuje. Bohužel právě u celostátních dokumentů vidíme velmi malou účast na procesu ze strany veřejnosti, mnohdy i ze strany odborníkủ a obcí. Společnost řeší vždy až následky toho, co ji př́mo, často negativně ovlivní, a teprve posléze to začíná řešit. PASK ČR pokládá obecnou vizi na stavební kulturu v České republice, její kvalitu a související kvalitu života. Avšak společnost se v malé míře zabývá i takovými dokumenty, jako jsou územní plány, které již mají konkrétní průmět do území a stanovují využití území a podmínky tohoto využití. I v tomto př́ípadě však role veřejnosti není naplňována a často se občané ozývají pozdě anebo při jejich negativních zkušenostech. $V$ tomto prípadě je důležitý veřejný zájem, který musí být nadřazen tomu soukromému. Veřejnost musí pochopit, že demokracie není jen o tom, co všechno člověk může, ale také jaké povinnosti každému plynout a jsou nastaveny určité společenské podmínky. Stavební kultura v České republice by tak bez podmínek, které stanovuje územní plánování velmi poklesla, nebot’ každý si roli pravidel neuvědomuje.

\section{ZÁVĚR}

Článek poukazuje na jeden ze strategických materiálu s celostátní působností, a to Politiku architektury a stavební kultury České republiky. Dokument prošel řadou změn, byl pravidelně vyhodnocován a v současnosti probíhá aktualizace dokumentu s termínem do konce roku 2022, na základě usnesení vlády, která rozhodla o aktualizaci. Před samotnou aktualizací byla provedena rozsáhlá analýza zaměřená na politiky architektury v ostatních zemích Evropy s vyhodnocením, zda a co konkrétně by bylo vhodné a účelné převzít i do českého celostátního dokumentu. Další analýza byla provedena na základě připomínek a doporučení profesních organizací a tyto názory byly opět vyhodnoceny, zda je možno je v materiálu aplikovat a implementovat. Na základě těchto analýz byl zpracován materiál pro jednání vlády, který byl schválen a udává směr, kterým se aktualizace PASK ČR dále orientuje. V současnosti probíhají jednání pracovní skupiny zř́zené za účelem aktualizace dokumentu, kde zástupci ministerstev, orgánů státní správy a dalších institucí řeší navrhované změny. Představení finálního materiálu by mělo být na mezinárodní konferenci při př́ležitosti předsednictví České republiky v Radě EU. Dalším krokem by mělo být zpracování materiálu pro širokou veřejnost, který bude graficky zajímavější, čitelnější a bude více přibližovat veřejnost s problematikou zlepšení kvality života lidí zvyšováním kvality prostředí, ve kterém žijí.

\section{Použité zdroje}

[1] Zákon č. 283/2021 Sb., stavební zákon

[2] The Davos Baukultur Quality Systém: Eight criteria for a high-quality Baukultur - the whole story. Berne: Swiss Federal Office of Culture, 2021.

[3] Zvyšování kultury výstavby - evropské fórum politik architektury. Brno: Ústav územního rozvoje, 2011. Dostupné také z: http://www.uur.cz/images/1-uzemni-planovani-a-stavebni-rad/politikaarchitektury/Zvysovani-kultury-vystavby-EFAP.pdf

[4] Analýza stavební kultury: Podklad pro řešení problematiky. Politika rozvoje stavební kultury (architektury). Brno: Ústav územního rozvoje, 2012. Dostupné také z: http://www.uur.cz/images/1uzemni-planovani-a-stavebni-rad/politika-architektury/Analyza-stavebni-kultury.pdf

[5] Politika architektury a stavební kultury České republiky. Praha, Brno: Ministerstvo pro místní rozvoj, Ústav územního rozvoje, 2015. ISBN 978-80-87147-83-2, 978-80-87318-34-8.

[6] Politika územního rozvoje České republiky. Brno: Ústav územního rozvoje. ISBN 978-80-87318-04-1.

[7] Politika územního rozvoje České republiky (ve znění závazném od 1. 9. 2021). Brno: Ústav územního rozvoje. ISBN 978-80-7663-019-2.

[8] Politika architektury a stavební kultury České republiky: Zpráva o plnění k prosinci 2017. Praha: Ministerstvo pro místní rozvoj, 2017. ISBN 978-80-7538-162-0.

[9] Politika architektury a stavební kultury České republiky: Vyhodnocení plnění k roku 2020. Praha, Brno: Ministerstvo pro místní rozvoj, Ústav územního rozvoje, 2021. ISBN 978-80-7538-310-5.

[10] Politika architektury a stavební kultury České republiky: Analýza zahraničních materiálů a doporučení. Praha,Brno: Ministerstvo pro místní rozvoj, Ústav územního rozvoje, 2020. ISBN 978-80-7538-2849.

[11] Politika architektury a stavební kultury České republiky: Analýza doporučení profesních organizací k aktualizaci dokumentu. Praha, Brno: Ministerstvo pro místní rozvoj, Ústav územního rozvoje, 2020. ISBN 978-80-7538-291-7, 978-80-87318-96-6.

[12] Politika architektury a stavební kultury České republiky: Náměty k aktualizaci. Praha, Brno: Ministerstvo pro místní rozvoj, Ústav územního rozvoje, 2021. ISBN 978-80-7538-311-2, 978-80-7663-008-6.

[13] Politika architektury a stavební kultury České republiky: Výsledky souhrnné analýzy výstupů k aktualizaci dokumentu. Praha, Brno: Ministerstvo pro místní rozvoj, Ústav územního rozvoje, 2021. ISBN 978-80-7538-347-1, 978-80-7663-010-9. 